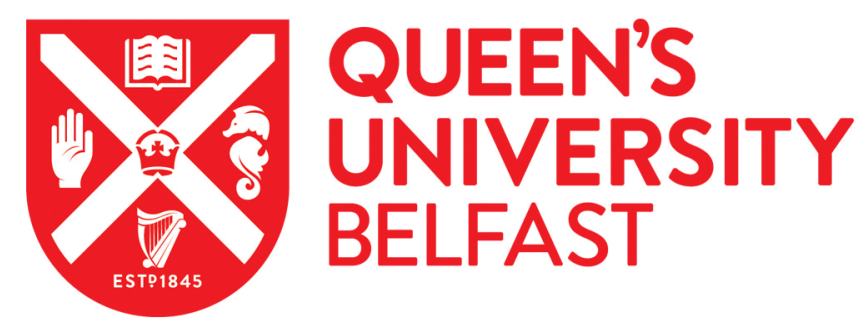

\title{
Gender inequality in academia: Problems and solutions for women faculty in STEM
}

Casad, B. J., Franks, J. E., Garasky, C. E., Kittleman, M. M., Roesler, A. C., Hall, D. Y., \& Petzel, Z. W. (2020). Gender inequality in academia: Problems and solutions for women faculty in STEM. Journal of Neuroscience Research. https://doi.org/10.1002/jnr.24631

Published in:

Journal of Neuroscience Research

Document Version:

Peer reviewed version

Queen's University Belfast - Research Portal:

Link to publication record in Queen's University Belfast Research Portal

Publisher rights

Copyright 2020 Wiley.

This work is made available online in accordance with the publisher's policies. Please refer to any applicable terms of use of the publisher.

\section{General rights}

Copyright for the publications made accessible via the Queen's University Belfast Research Portal is retained by the author(s) and / or other copyright owners and it is a condition of accessing these publications that users recognise and abide by the legal requirements associated with these rights.

Take down policy

The Research Portal is Queen's institutional repository that provides access to Queen's research output. Every effort has been made to ensure that content in the Research Portal does not infringe any person's rights, or applicable UK laws. If you discover content in the Research Portal that you believe breaches copyright or violates any law, please contact openaccess@qub.ac.uk. 


\title{
Gender Inequality in Academia: Problems and Solutions for Women Faculty in STEM
}

\begin{abstract}
Recently there is widespread interest in women's underrepresentation in science, technology, engineering, and mathematics (STEM); however, progress towards gender equality in these fields is slow. More alarmingly, these gender disparities worsen when examining women's representation within STEM departments in academia. While the number of women receiving postgraduate degrees has increased in recent years, the number of women in STEM faculty positions remains largely unchanged. One explanation for this lack of progress towards gender parity is negative and pervasive gender stereotypes, which may facilitate hiring discrimination and reduce opportunities for women's career advancement. Women in STEM also have lower social capital (e.g., support networks), limiting women's opportunities to earn tenure and learn about grant funding mechanisms. Women faculty in STEM may also perceive their academic climate as unwelcoming and threatening, and report hostility and uncomfortable tensions in their work environments, such as sexual harassment and discrimination. Merely the presence of gender biased cues in physical spaces targeted toward men (e.g., "geeky" décor) can foster a sense of not belonging in STEM. We describe three factors that likely contribute to gender inequalities and women's departure from academic STEM fields: (1) numeric underrepresentation and stereotypes, (2) lack of supportive social networks, and (3) chilly academic climates. We discuss potential solutions for these problems, focusing on NSF-funded ADVANCE organizational change interventions that target (1) recruiting diverse applicants (e.g., training search committees), (2) mentoring, networking, and professional development (e.g., promoting women faculty networks); and (3) improving academic climate (e.g., educating male faculty on gender bias).
\end{abstract}




\section{Significance Statement}

Women remain underrepresented in the STEM academic workforce due to systemic gender inequalities including numeric underrepresentation, lower social capital, and threatening academic climates. We review effective interventions that offer best practices for recruiting women in STEM, providing mentoring, networking, and professional development, and improving academic climate. The interventions focus on systemic issues that through academic cultural change can reduce inequities for women in the STEM academic realm. Resources are provided to help academics and administrators collaborate with social scientists in developing and implementing interventions within their organizations.

\section{Gender Inequality in Academia: Problems and Solutions for Women Faculty in STEM}

There has been a recent proliferation of research on women's underrepresentation in science, technology, engineering, and mathematics (STEM). Despite the continued enthusiasm

for this research and a wealth of evidence demonstrating the consequences of gender disparities, gender inequalities in STEM remain largely unchanged. While women earn $54.8 \%$ of conferred baccalaureate degrees in the social and biological sciences and $42.4 \%$ in mathematics and statistics, women are underrepresented in computer science $(18.7 \%)$, the physical sciences (19.3\%), and engineering (20.9\%; National Science Foundation [NSF], 2019a; see Table 1). Adding to these concerns, women of color comprise less than $5 \%$ of undergraduates in maledominated STEM fields (NSF, 2019a). Women remain underrepresented at the graduate level, earning $20.1 \%$ of doctorates in computer science, $19.3 \%$ in the physical sciences, $23.5 \%$ in engineering, and $28.5 \%$ in mathematics and statistics, a decrease from baccalaureate rates (NSF, 2019a). Only 5\% of all science and engineering doctorates are awarded to women of color (NSF, 2019a). 
Table 1. Gender Disparities in STEM Degree Attainment for all Women

\begin{tabular}{|l|c|c|}
\hline & Baccalaureate Degrees & Doctoral Degrees \\
\hline $\begin{array}{l}\text { Social and Biological } \\
\text { Sciences }\end{array}$ & $54.8 \%$ & $48.8 \%$ \\
\hline $\begin{array}{l}\text { Mathematics and } \\
\text { Statistics }\end{array}$ & $42.4 \%$ & $28.5 \%$ \\
\hline Computer Science & $18.7 \%$ & $20.1 \%$ \\
\hline Physical Sciences & $19.3 \%$ & $19.3 \%$ \\
\hline Engineering & $20.9 \%$ & $23.5 \%$ \\
\hline
\end{tabular}

The gender gap further widens in academic positions, with these disparities extending into female-dominated undergraduate fields (e.g., biological sciences). For example, women account for $31 \%$ of academic positions in neuroscience across all faculty ranks (McDermott et al., 2018). Besides numeric underrepresentation, women faculty in STEM have lower publication rates compared to men (McDermott et al., 2018) and are perceived as less competent than men by grant reviewers for the National Institutes of Health (Magua et al., 2017). However, a recent report (Huang, Gates, Siantra, \& Barabasi, 2020) suggests men and women publish at similar rates and have similar career outcomes based on total number of publications. The gender gap in publishing can be explained by gender differences in career lengths in STEM, with women more likely to have shorter publishing careers and higher dropout rates than men. These gender disparities are not exclusive to the USA, with countries around the world reporting similar trends across STEM disciplines (Salmon, 2015; WISE, 2019). While countries have implemented systematic initiatives to reduce gender gaps in higher education, such as Athena SWAN in the UK and SEA Change in the USA, progress towards gender parity in academic STEM fields is slow.

In this selective review, we emphasize three factors in academia that contribute to gender inequalities in STEM: (1) the numeric underrepresentation of women, with additional disparities 
specific to women of color; (2) lower social capital, or access to powerful social networks and interpersonal relationships that provide privileges such as resources (Collins \& Steffen, 2019; Korte \& Lin, 2013; Rhoten \& Pfirman, 2007); and (3) threatening academic climates. Our primary focus is on gender disparities but take note of additional inequities for women of color since they not only contend with sexism in academia but also racism. We do not focus on men of color because there is much less research focused on this group and they are vastly underrepresented in academia (earning 3.8\% of doctorates in STEM) compared to White men. Further, federal grants and interventions have primarily targeted women in STEM. In addition to describing the problems facing women faculty in STEM, we provide a selective review of potential solutions to these inequalities informed by federally funded interventions that aim to recruit more women faculty in STEM, provide mentoring, networking, and professional development, as well as improve academic climates.

\section{Causes and Consequences of Gender Inequality in STEM}

\section{Underrepresentation of Women}

Underrepresentation of women in STEM faculty positions at research institutions is often attributed to fewer women obtaining advanced degrees than men (Griffith, 2010). However, despite more women earning doctorates in STEM than before, the number of women in STEM faculty positions has not increased (Carrigan, Quinn, \& Riskin, 2011; Ginther \& Kahn, 2013). Emerging evidence suggests this underrepresentation is more attributable to disadvantages rather than merit, such as negative experiences women face within STEM departments related to stereotypes favoring men (Rosser, 2004). Women faculty of color experience a double bind, in which they face discrimination and oppression based on their race and gender (Malone \& Barabino, 2009). 
Stereotypically masculine characteristics (e.g., independence, competitiveness) are more valued in STEM departments than stereotypically feminine characteristics (e.g., communal, nurturing) rendering men more promotable and perceived as better suited for leadership positions (Lester, 2008). As a result of these stereotypes, women who seek faculty positions in STEM often experience hiring discrimination and limited opportunities for advancement, making these jobs less attractive to women, which leads to higher attrition (Diekman, et al., 2015; Kaminski \& Geisler, 2012). Further, once an academic career in STEM is acquired, women are two times more likely to leave compared to men (Ceci et al., 2009; Seifert \& Umbach, 2008). Although STEM faculty tend to be equally committed to their academic careers regardless of gender, women are more likely to change academic positions (Settles et al. 2006; Valian, 2005; Xu, 2008) and are less likely to be awarded tenure than men (Curtis, 2014). At the top fifty research universities in the USA, women hold $31 \%$ of the tenured or tenured-track faculty positions while women of color hold less than $2 \%$ of tenured or tenured-track faculty positions (NSF, 2019a).

One factor contributing to the disproportionate turnover rate is higher expectations placed on women faculty in STEM. Women faculty are expected to perform communal roles within the department, often being assigned higher teaching loads (Carrigan, Quinn, \& Riskin, 2011; Eveline, 2004) and tend to feel more obligated to mentor large numbers of students (Lester, 2008). Students perceive women faculty as more approachable, resulting in greater work requests, special favors, and friendship behaviors than men faculty (El-Alayli, Hansen-Brown, \& Ceynar, 2018). Furthermore, students have greater expectations that their requests will be met by women faculty compared to men (El-Alayli et al., 2018).

Given the numeric underrepresentation of women faculty, particularly women of color, in STEM, they are assigned more service activities compared to men because committees often 
seek a "token" diverse member in every group, which takes up valuable time (Bagilhole, 2017; Belle, Smith-Doerr, \& O’Brien, 2014; Kachchaf, Ko, Hodari, \& Ong, 2015). While mentoring and service activities are important for thriving universities, these extra burdens placed on women can be detrimental to their careers. With most of their valuable time already accounted for, women have less time to conduct their own research, which negatively affects publishing, earning tenure, obtaining research grants, and advancing their careers.

\section{Social Capital}

Gender disparities among STEM faculty are also related to women's lower social capital, or access to powerful social networks and interpersonal relationships that provide privileges such as material resources, networks, and other benefits that support career advancement (Collins \& Steffen, 2019; Korte \& Lin, 2013; Rhoten \& Pfirman, 2007). For example, male faculty tend to have an easier time establishing networks with research collaborators (Abramo, D’Angelo, \& Murgia, 2013; Collins \& Steffen, 2019), more knowledge of research funding opportunities (Etzkowitz et al., 2000), are more likely to achieve tenure (Curtis, 2014), and are more likely to be promoted to leadership positions $(\mathrm{Xu}, 2008)$. Lower social capital also negatively impacts relationships with co-workers and direct supervisors, which increases social isolation among women faculty and decreases one's ability to integrate into their STEM field (Korte \& Lin, 2013). Women faculty in STEM report a lack of formal mentoring, limited ability to network and collaborate on research projects, lack of guidance and expectations on how to achieve tenure, and feelings of isolation within their departments (Smith, 2014).

Lower social capital is demonstrated by smaller professional networks and exclusion from "power circles" where most of the major decisions within STEM departments are made and funding opportunities are discussed (Smith, 2011). Solo status in predominantly white, male- 
dominated networks can lead to women's greater difficulty in securing grants compared to their male counterparts (Bozeman \& Corley, 2004; Rosser, 2004). Due to limited network exposure and involvement in departmental decisions, women faculty have limited career-advancing opportunities (Collins \& Steffen, 2019). Additionally, the lack of racial diversity within STEM leads to experiences of isolation and lower social support for women of color (Towns, 2010). Limited networking exposure discourages women of color from addressing racial diversity issues on campus, which negatively affects perceptions of university commitment to address racerelated issues (Malone \& Barabino, 2009).

The higher turnover rate of women in STEM can also be attributed to limited social capital such as less research support, fewer advancement opportunities, and less support for the expression of one's ideas $(\mathrm{Xu}, 2008)$. Finally, women tend to lack social capital as demonstrated by receiving smaller lab spaces, lower salaries, and fewer prestigious opportunities compared to their male counterparts (Rosser \& O’Neil Lane, 2002; Walters \& McNeely, 2010).

\section{Academic Climate}

Research overwhelmingly demonstrates the academic climate for women in STEM is chilly (Casad, Petzel, \& Ingalls, 2019; Cheryan, Plaut, Davies, \& Steele, 2009; Gunter \& Stambach, 2005; Miner, January, Dray, \& Carter-Sowell, 2019; Riffle et al., 2013; Settles et al., 2006; Willemsen \& van Vianen, 2014). Chilly, unwelcoming, and threatening academic environments discourage women from becoming professors and predict women leaving academia (Riffle et al., 2013). Women faculty in STEM experience greater ostracism and incivility compared to male faculty in STEM (Miner et al., 2019). Further, women faculty in STEM report feeling more hostility, tension, and discomfort in their work environments compared to male faculty in STEM (Gunter \& Stambech, 2005). Perceptions of chilly climate in 
academic departments predict lower job satisfaction and greater intentions to quit (Callister, 2006). For example, greater experiences of sexual harassment and gender discrimination predict lower job satisfaction, feeling less influential, and less productivity (Settles et al., 2006). In contrast, positive, non-sexist environments with effective leaders predict greater job satisfaction, feeling more influential, and more productivity (Settles et al., 2006).

Whether an academic climate is perceived as chilly or supportive for women is determined by many environmental factors beyond sexual harassment and gender discrimination (see Casad \& Bryant, 2016). Although less obvious than blatant harassment and discrimination, subtle cues in an environment, including physical spaces, can unintentionally communicate threatening messages of exclusion (Cheryan et al., 2009). For example, offices or lab spaces with stereotypical masculine décor, such as "geeky" references to pop culture (e.g., Star Trek posters, video game memorabilia), or reading materials targeted to a predominantly white or male audience can communicate underrepresented groups do not belong in STEM (Cheryan et al., 2009; Cohen \& Garcia, 2008). Other environmental cues are less tangible including diversity messages communicated on institutional websites and through employment offer letters. The language used on websites and in letters has the potential to signal to underrepresented groups, both applicants and current employees, that they do not belong ( $\mathrm{Ng} \&$ Burke, 2005; Walker, Feild, Bernerth, \& Becton, 2012). For example, corporations that advertise their voluntary adoption of diversity management, or policies and actions that promote inclusion of employees from diverse gender, race, and national backgrounds, are more attractive to diverse job applicants (Ng \& Burke, 2005). Further, offer letters can differ in tone, which is perceived by diverse job candidates as warm and welcoming (e.g., "we understand starting a new job can be overwhelming" and "help make your transition easier") or cold and unwelcoming (e.g., 
communicating independence and competitiveness; see Ng \& Burke, 2005, p. 1206-1207;

Stephens, Fryberg, \& Markus, 2012). Institutional mission statements often communicate ideologies regarding diversity, and if viewed as supportive of diversity, positively affect diverse individuals' commitment to the organization (Purdie-Vaughns, Steele, Davies, Ditlmann, \& Crosby, 2008). However, environments promoting stereotypes lead underrepresented groups to question their belonging in that institution (Elsbach, 2003).

A negative consequence of threatening academic climates is stereotype threat (Casad et al., 2019), which is a state of fear, anxiety, and heightened physiological arousal that arises when a member of a stigmatized group worries about confirming a negative stereotype about their gender or racial group (Schmader, Johns, \& Forbes, 2008; Steele \& Aronson, 1995). Stereotype threat can lead to many negative outcomes for women in STEM including reduced leadership aspirations (Burgess, Joseph, Van Ryn, \& Carnes, 2012), feelings of incompetence, lower perceived acceptance, mental fatigue, and job burnout (Hall, Schmader, \& Croft, 2015). Women in STEM report experiencing stereotype threat more often than men and lower sense of belonging, which predicts more negative beliefs about career advancement despite having similar connectedness with one's career and colleagues (Fassiotto et al., 2016).

\section{Institutional Interventions in STEM}

Federal granting agencies including the National Institutes of Health (NIH) and the National Science Foundation (NSF) have developed grant mechanisms to investigate causes and find remedies for gender and race disparities in STEM education and careers, and to support diverse researchers, such as the "Broadening Participation" programs (Committee on Underrepresented Groups, 2011; James \& Singer, 2016). One longstanding NIH program, "Research to Understand and Inform Interventions that Promote the Research Careers of 
Individuals in the Biomedical Sciences," funds research in the areas of effective training programs, psychosocial factors, navigating critical transition points, and institutional factors influencing persistence (NIH, 2019). In addition, NIH has altered its policies to support women scientists' career advancement such as extending early career researcher status for women who recently have given birth (see https://extramural-diversity.nih.gov/diversity-matters/womenworkforce).

The interventions of interest in this review were funded by NSF "ADVANCE: Organizational Change for Gender Equity in STEM Academic Professions” grant mechanisms that aim at developing new and sustainable ways to promote equality in the STEM academic workforce (see Table 2; NSF, 2019b). We chose to focus on this NSF grant mechanism above others because it focuses not only on testing the effectiveness of interventions, but on implementing interventions at university and system levels, making systemic policy changes, and institutionalizing these organizational changes. For this reason, we believe the NSF ADVANCE program is transformative and should serve as a model for diversity, equity, and inclusion efforts in STEM.

Between 2001 and 2018 the NSF awarded over \$270 million to 177 institutions in the USA with the mission of increasing the participation and advancement of women in academic STEM fields (NSF, n.d.). The goal of the ADVANCE program is to provide funding to create diverse and inclusive academic environments through evidence-based practices including educating and empowering women and men through interventions. Much of the work focuses on systematic approaches to research and systemic factors causing inequalities in academia. Many of the ADVANCE funded institutions have developed interventions to increase the 
representation of women in STEM through recruitment, retention, and promotion, and cultivating a positive campus climate through dialogue, awareness, and fair policies.

\section{Recruiting Women in STEM}

One way to address the underrepresentation of women faculty in STEM is to modify recruitment efforts to reach a diverse applicant pool. Search committee members also need training to reduce implicit gender and race biases in the selection process. Several ADVANCE interventions have successfully addressed these issues.

Researchers at Montana State University implemented a recruitment intervention for search committees using a three-step process informed by self-determination theory addressing competency, autonomy, and relatedness (Deci \& Ryan 1985; 2000). The three components of the intervention consisted of providing a short presentation on implicit bias to the search committee, providing the search committee with a toolkit for recruiting diverse candidates, connecting search committee members with supportive peer faculty, and connecting the job candidate with a "family advocate" to discuss work-life balance (Smith, Handley, Zale, Rushing, \& Potvin, 2015). The intervention was effective. Search committees that received the intervention offered more tenure-track faculty positions in STEM to women applicants than search committees that did not receive the intervention (Smith et al., 2015). However, implementing such interventions is not always free of push-back. Some faculty members expressed a fear of selecting under qualified candidates if special attention was put on filling a gender quota. However, research suggests that when faced with the dilemma of selecting a candidate, women candidates who are perceived as slightly less accomplished than their male counterparts do not have a significant gender advantage in the hiring process, and were in fact bypassed for a slightly more superior male candidate $95.2 \%$ of the time (Ceci \& Williams, 2015). Push-back to such interventions can also 
come in the form of lack of receptiveness. Some of the five Florida State Universities in the process of improving recruitment practices reported variation in faculty receptiveness to recruitment training (Fernandez, Popović, \& Gilmer, 2014).

Table 2. Overview of Selected NSF ADVANCE Funded Interventions

\begin{tabular}{|c|c|c|}
\hline Primary Aim and Methods & $\begin{array}{c}\text { Institutional Examples and } \\
\text { Resources }\end{array}$ & Limitations* \\
\hline \multicolumn{3}{|c|}{ Recruiting Women in STEM } \\
\hline $\begin{array}{l}\text { Train search committee } \\
\text { members on implicit bias; } \\
\text { provide resources for } \\
\text { recruiting diverse faculty; } \\
\text { provide faculty mentors for } \\
\text { search committee members; } \\
\text { provide a family advocate for } \\
\text { job candidates }\end{array}$ & $\begin{array}{l}\text { Montana State University } \\
\text { (Smith et al., 2015) } \\
\underline{\text { http://www.montana.edu/nsfa }} \\
\underline{\text { dvance/ }} \\
\text { Florida State Universities } \\
\text { (Fernandez et al., 2014) } \\
\underline{\text { https://ww2.eng.famu.fsu.edu }} \\
\text { / peterson/AAFAWCE/aafa } \\
\text { wce.html }\end{array}$ & $\begin{array}{l}\text { Committee members not } \\
\text { recognizing their own } \\
\text { implicit biases, resistance to } \\
\text { change, fear of "Affirmative } \\
\text { Action quotas" resulting in } \\
\text { less qualified candidates } \\
\text { (Ceci \& Williams, 2015) }\end{array}$ \\
\hline $\begin{array}{l}\text { Conduct focus groups with } \\
\text { faculty to develop best } \\
\text { practices; actively recruit } \\
\text { high-quality women from } \\
\text { high producing universities; } \\
\text { invite prospective job } \\
\text { candidates through } \\
\text { Distinguished Postdoctoral } \\
\text { and Doctoral Student } \\
\text { Seminars }\end{array}$ & $\begin{array}{l}\text { California State Polytechnic } \\
\text { University in Pomona } \\
\text { (Nemiro et al., 2009) }\end{array}$ & $\begin{array}{l}\text { The high-quality job } \\
\text { candidates may not apply to } \\
\text { the host institution; the talent } \\
\text { pool from highly sought-after } \\
\text { sources is highly competitive } \\
\text { and lower ranked, less } \\
\text { prestigious universities are } \\
\text { disadvantaged }\end{array}$ \\
\hline $\begin{array}{l}\text { Identify biases in recruitment; } \\
\text { include a diversity statement } \\
\text { in the application materials; } \\
\text { allow applicants to showcase } \\
\text { their civic and scholarly } \\
\text { engagement with diversity }\end{array}$ & $\begin{array}{l}\text { University of California, } \\
\text { Davis } \\
\text { (University of California } \\
\text { Office of the General } \\
\text { Counsel, 2015) } \\
\text { https://ucd- } \\
\underline{\text { advance.ucdavis.edu/ }}\end{array}$ & $\begin{array}{l}\text { Diversity statements need to } \\
\text { be well-crafted or they can } \\
\text { backfire and discourage } \\
\text { diverse applicants (Carnes et } \\
\text { al., 2018); awarding service } \\
\text { and engagement with } \\
\text { diversity requires top-level } \\
\text { endorsement (e.g., for tenure } \\
\text { and promotion) }\end{array}$ \\
\hline $\begin{array}{l}\text { Video Interventions for } \\
\text { Diversity (VIDS)^ increased } \\
\text { awareness of bias, decreased } \\
\text { gender bias, and decreased }\end{array}$ & $\begin{array}{l}\text { Skidmore College, Indiana } \\
\text { University-Purdue University } \\
\text { Indianapolis } \\
\text { (Hennes et al., 2018) }\end{array}$ & $\begin{array}{l}\text { Unintended consequences to } \\
\text { gender diversity } \\
\text { interventions, e.g., women's } \\
\text { sense of belonging in STEM }\end{array}$ \\
\hline
\end{tabular}




\begin{tabular}{|c|c|c|}
\hline $\begin{array}{l}\text { sexism among STEM faculty } \\
\text { and the general public }\end{array}$ & $\begin{array}{l}\text { (Moss-Racusin et al., 2018) } \\
\text { (Pietri et al., 2017) } \\
\text { https://academics.skidmore.e } \\
\underline{\text { du/blogs/vids/ }} \\
\underline{\text { https://www.pietrilab.com/res }} \\
\text { earch }\end{array}$ & $\begin{array}{l}\text { (Pietri et al., 2019); less } \\
\text { identification with actors if } \\
\text { they do not represent the } \\
\text { targeted audience }\end{array}$ \\
\hline $\begin{array}{l}\text { Interactive theatre workshop; } \\
\text { integrated performance artists } \\
\text { and STEM faculty; facilitated } \\
\text { discussions on reasons for } \\
\text { gender disparities and how } \\
\text { bias influences decisions; } \\
\text { effective in improving } \\
\text { university climate and } \\
\text { women's representation }\end{array}$ & $\begin{array}{l}\text { University of New Hampshire } \\
\text { (Shea et al., 2019) } \\
\text { https://paulcollege.unh.edu/pe } \\
\underline{\text { rson/christine-shea }}\end{array}$ & $\begin{array}{l}\text { Less identification with actors } \\
\text { if they do not represent the } \\
\text { targeted audience; skit } \\
\text { enactments need to reflect } \\
\text { real experiences; discussion } \\
\text { needs to be led by an expert } \\
\text { facilitator }\end{array}$ \\
\hline \multicolumn{3}{|c|}{ Mentoring, Networking, and Professional Development } \\
\hline $\begin{array}{l}\text { Retaining and promoting } \\
\text { current faculty by clearly } \\
\text { defining the process for } \\
\text { promotions; faculty } \\
\text { mentoring program; bias } \\
\text { literacy; training search } \\
\text { committees }\end{array}$ & $\begin{array}{l}\text { University of Wisconsin- } \\
\text { Madison } \\
\text { (Savoy, 2013) } \\
\text { (Sheridan et al., 2004) } \\
\text { https://wiseli.wisc.edu/ }\end{array}$ & $\begin{array}{l}\text { Resistance from faculty who } \\
\text { do not feel they need training; } \\
\text { new faculty feeling stigma for } \\
\text { "needing" a mentor (Austin } \\
\text { \& Laursen, 2014); mentors } \\
\text { need to be skilled, including } \\
\text { socioemotional skills } \\
\text { (Handelsman et al., 2005; } \\
\text { Pfund et al., 2013) }\end{array}$ \\
\hline $\begin{array}{l}\text { Committee of five senior } \\
\text { faculty members to mentor } \\
\text { first year hires }\end{array}$ & $\begin{array}{l}\text { University of Michigan } \\
\text { https://advance.umich.edu/pr } \\
\text { ograms/launch-committees/ }\end{array}$ & $\begin{array}{l}\text { Mentors need to be trained } \\
\text { and committed; burden on } \\
\text { mentors, particularly in small } \\
\text { departments }\end{array}$ \\
\hline $\begin{array}{l}\text { Diversity Mentor Professor } \\
\text { Program; targeted recruitment } \\
\text { of existing faculty with } \\
\text { demonstrated mentorship } \\
\text { skills to mentor women and } \\
\text { racial minority students and } \\
\text { faculty }\end{array}$ & $\begin{array}{l}\text { Florida International } \\
\text { University } \\
\text { https://advance.fiu.edu/progra } \\
\text { ms/diversity-mentor- } \\
\text { professorships/index.html }\end{array}$ & $\begin{array}{l}\text { Mentors need to be trained } \\
\text { and committed; burden on } \\
\text { mentors, particularly in small } \\
\text { departments; new faculty } \\
\text { feeling stigma for "needing" } \\
\text { a mentor (Austin \& Laursen, } \\
\text { 2014) }\end{array}$ \\
\hline $\begin{array}{l}\text { Women Faculty Network; } \\
\text { empower faculty to advance } \\
\text { their professional and } \\
\text { personal development; } \\
\text { advertise women's } \\
\text { achievements through a } \\
\text { newsletter; recognition and } \\
\text { support from community }\end{array}$ & $\begin{array}{l}\text { University of Texas Rio } \\
\text { Grande Valley } \\
\text { https://www.utrgv.edu/acade } \\
\text { micaffairs/council-and- } \\
\text { committees/womens-faculty- } \\
\underline{\text { network/index.htm }} \\
\underline{\text { https://www.utrgv.edu/advan }} \\
\underline{\text { ce/_files/documents/wfnnews }} \\
\text { letterspring_2018.pdf }\end{array}$ & $\begin{array}{l}\text { "Networking activities may } \\
\text { not focus on the specific } \\
\text { needs of an individual faculty } \\
\text { member. Individuals may } \\
\text { need to identify those within } \\
\text { the mentoring network who } \\
\text { can be most helpful in regard } \\
\text { to specific questions or } \\
\text { issues" (Austin \& Laursen, } \\
2014, \text { p. } 7 \text { ) }\end{array}$ \\
\hline
\end{tabular}




\begin{tabular}{|c|c|c|}
\hline \multicolumn{3}{|l|}{ Improving Academic Climate } \\
\hline $\begin{array}{l}\wedge \text { Scientific Diversity; active } \\
\text { learning about the research on } \\
\text { gender bias; how to share the } \\
\text { collective responsibility of } \\
\text { reducing bias in STEM }\end{array}$ & $\begin{array}{l}\text { Skidmore College } \\
\text { (Moss-Racusin et al., 2014; } \\
\text { 2015) }\end{array}$ & $\begin{array}{l}\text { May elicit justifications for } \\
\text { gender bias (Moss-Racusin et } \\
\text { al., 2015) }\end{array}$ \\
\hline $\begin{array}{l}\text { Bystander interventions; } \\
\text { Intervention for men to learn } \\
\text { how to intervene during } \\
\text { misconduct; focus on field } \\
\text { sciences where research and } \\
\text { training is off-campus and } \\
\text { there are little to no support } \\
\text { networks and clear guidelines } \\
\text { for conduct }\end{array}$ & $\begin{array}{l}\text { University of Wisconsin- } \\
\text { Madison; Colorado College; } \\
\text { University of California, } \\
\text { Merced; Brown University; } \\
\text { California State University, } \\
\text { Los Angeles; University of } \\
\text { Kansas } \\
\text { (Marin-Spiotta et al., 2017) } \\
\text { https://serc.carleton.edu/adva } \\
\text { ncegeo/index.html }\end{array}$ & $\begin{array}{l}\text { Intervention should provide } \\
\text { training on other types of } \\
\text { harassment besides sexual, } \\
\text { particularly harassment } \\
\text { toward women with } \\
\text { intersectional identities (e.g., } \\
\text { racism, ableism, } \\
\text { heterosexism); resistance } \\
\text { from faculty who do not think } \\
\text { they "need" this training }\end{array}$ \\
\hline $\begin{array}{l}\text { Workshop Activity for } \\
\text { Gender Equity Simulation } \\
\text { (WAGES) to educate faculty } \\
\text { on gender biases in STEM; } \\
\text { recognizing the negative } \\
\text { effects of unfair practices; } \\
\text { developing awareness of how } \\
\text { unfair practices affect women } \\
\text { differently during different } \\
\text { stages of their career; } \\
\text { recognizing patterns within } \\
\text { their own workplace }\end{array}$ & $\begin{array}{l}\text { Penn State } \\
\text { (Cundiff et al., 2014) } \\
\text { (Mitchneck, 2008) } \\
\text { https://wages.la.psu.edu/ }\end{array}$ & $\begin{array}{l}\text { Faculty buy-in may be an } \\
\text { issue; recognizing and } \\
\text { acknowledging one's own } \\
\text { role in perpetuating subtle } \\
\text { gender biases }\end{array}$ \\
\hline
\end{tabular}

Notes. ${ }^{*}$ The suggested limitations reflect our views unless otherwise cited. ^ ${ }^{\wedge}$ his work was funded by the Alfred P. Sloan Foundation Grants \#213-3-15, \#B2013-38, and Howard Hughes Medical Institute. ${ }^{\wedge}$ This work was funded by the grants mentioned above $\left({ }^{\wedge}\right)$ as well as NIH grant 1R13GM090574-01. The non-ADVANCE interventions are included because they are easy to implement, scalable, freely available, and produced and tested by well-known scholars in STEM diversity science.

Other forms of interventions include focus groups, diversity statements, Video Interventions for Diversity (VIDS), and interactive theatre workshops in order to change and expand recruitment processes. California State Polytechnic University in Pomona used focus 
groups comprised of women tenure-track and tenured faculty in the Colleges of Science and Engineering to develop best practices for recruiting, developing, and retaining women faculty in STEM (Nemiro, Hacker, Ferrel, \& Guthrie, 2009). Some of the interventions suggested by the focus group included creating an active rather than passive search for women faculty, for example, becoming familiar with institutions that produce high-quality women candidates in their respective field. For instance, the ADVANCE Distinguished Postdoctoral and Doctoral Student Seminars invited talented women Ph.D. candidates and postdoctoral scholars to give seminars. This intervention compelled institutions to seek out the women candidates and highlighted the hosting institution as a potential place of future employment (Nemiro et al., 2009).

The University of California, Davis (UCD) has established the Strength through Equity and Diversity (STEAD) faculty search committee (University of California Office of the General Counsel, 2015). This committee holds workshops aimed at identifying bias in the recruitment process with the goal of increasing the likelihood of identifying and hiring diverse scholars. In addition, by including a diversity statement in the candidate application process, UCD communicates to potential job candidates that administrators are committed to their mission of fostering diverse learning environments for their students and a diverse academic environment for their faculty. Incorporating a diversity statement from the outset of recruitment has many advantages. First, it not only gives candidates an opportunity to showcase their types of civic and scholarly engagement that align with UCD's commitment to diversity, but also sends a message to the candidate that they will be joining a community where diversity is valued and may in turn increase diversity within the application pool. Second, the diversity statement acts as a means of compensating women for their service and advising, which often goes unrecognized due to their 
lack of representation in their department or field (University of California Office of the General Counsel, 2015).

Another intervention includes Video Intervention for Diversity (VIDS) in STEM. Video interventions are easily administered, scalable, and have been shown to increase awareness of bias, decrease gender bias, and decrease sexism (Hennes et al., 2018). A similar intervention demonstrated comparable results in both men and women, in the general public, and among STEM faculty (Moss-Racusin et al., 2018).

An interactive theatre workshop, an intervention that integrated performance artists and STEM faculty, used professional actors and a facilitator to guide faculty through discussions and situations involving why women faculty in STEM are underrepresented, focusing on how bias can impact decisions (Shea, Malone, Young, \& Graham, 2019). Findings indicated the intervention was effective in improving faculty diversity climate and led to increases in the number of women faculty at the university, as corroborated by multiple data sources indicating the intervention was a significant driving force in increasing women's representation (Shea et al., 2019).

\section{Mentoring, Networking, and Professional Development}

Interventions for women in STEM should extend beyond the recruitment process and focus on retaining and promoting current faculty and researchers. The Women in Science and Engineering Leadership Institute (WISELI; https://wiseli.wisc.edu/) at the University of Wisconsin-Madison emphasizes the importance of clearly defining the process for promotions and recognizes the importance of pairing new faculty members with a mentor (WISELI, 2015).

The Launch Program at the University of Michigan consists of a committee of five senior faculty members to mentor first year hires (ADVANCE Program University of Michigan; 
https://advance.umich.edu/programs/launch-committees/). The mentorship extends from the time the faculty member is hired to the end of their first academic year. Due to the program's success in the College of Engineering, School of Information, and the Department of Natural Sciences, the Launch program is expanding to the Social Sciences and Humanities.

Funding provided by the ADVANCE Institutional Transformation mechanism has allowed Florida International University to establish a Diversity Mentor Professor Program (FIU ADVANCE, 2019; https://advance.fiu.edu/programs/diversity-mentorprofessorships/index.html). This program aims to recruit STEM faculty who have demonstrated a commitment to mentoring women and underrepresented minority students in STEM. Recruiting faculty specifically for their mentorship abilities will affect both the retention of underrepresented faculty and minority students, therefore enriching the learning environment and diversifying the pipeline of baccalaureate and graduate students.

The final intervention comes in the form of making connections with and strengthening networks with women faculty who are already at an institution. In 2012, the University of Texas Rio Grande Valley established the Women Faculty Network (WFN;

https://www.utrgv.edu/academicaffairs/council-and-committees/womens-facultynetwork/index.htm). The mission of the WFN is to empower women faculty to advance their professional and personal development. One way this network supports its members is by advertising women's academic, teaching, service, and creative achievements through a newsletter. Through the publication of this newsletter women can see the accomplishments of fellow women colleagues and feel recognized and supported by their community (https://www.utrgv.edu/advance/_files/documents/wfnnewsletterspring_2018.pdf). 
Readers may argue that providing mentorship, networking, and professional development are common practices in many intuitions that are offered to new faculty regardless of gender or discipline. However, these programs vary in whether they are formal or informal and structured or unstructured. The ADVANCE interventions discussed herein are typically formal and structured and differ from standard programs because of their intentional focus on women faculty in male-dominated disciplines and their unique needs that differ from men. For example, women in STEM often report feeling isolated and lack a sense of belonging, particularly women of color, whereas men in STEM do not (Smith, 2014; Towns, 2010). Interventions with women must include programming that develops a sense of belonging and inclusion with STEM. Further, most male faculty, even junior ones, have larger research networks of collaborators and mentors in STEM (Bozeman \& Corley, 2004; Rosser, 2004), due to greater social capital, therefore targeting network building for women in STEM is necessary. Many networking programs are offered solely to women, such as the Women Faculty Network at University of Texas Rio Grande Valley. Finally, mentoring programs and professional development regarding leadership targeted at women in STEM prepare women to be the future leaders at universities so they can become change agents to address gender inequities (Austin \& Laursen, 2014).

\section{Improving Academic Climate}

One intervention to improve academic climates in STEM used a "Scientific Diversity" approach to teach life science faculty members about their biases (Moss-Racusin et al., 2015). The sessions used an active learning approach that encouraged faculty members to learn about and discuss the research on gender bias, how bias affects decisions and outcomes, and how to share the collective responsibility of reducing bias in STEM. Both directly after the training and two weeks later, participants reported lower gender bias against women in STEM. 
An ADVANCE grant awarded to a collaborative of eight institutions in partnership with the Earth Science Women's Network, the Association for Women Geoscientists, and the American Geophysical Union had the goal of improving academic climates in STEM at both the institutional and individual levels (Marin-Spiotta et al., 2019). To approach the issue from a structural level, researchers informed administrative leaders about the issues faced by underrepresented groups in STEM to create buy in, implementing policies and procedures that work to eliminate current disparities in STEM, and providing interventions to men in STEM to learn about the gender disparities and how to intervene during misconduct (Marin-Spiotta et al., 2017). On a smaller scale, Penn State was awarded an ADVANCE grant to adapt and implement a workshop to educate faculty on gender biases in STEM (Workshop Activity for Gender Equity Simulation; WAGES). The intervention had three learning objectives, which included recognizing the negative effects of unfair practices that hold women back from advancing in the field, developing awareness about how unfair practices affect women differently during different stages of their career, and recognizing the patterns within their own workplace (Mitchneck, 2008).

While these are only a small sample of the 177 grants awarded through ADVANCE, many have the same goal: to increase the representation of women in STEM through fair policies, interventions, and a positive organizational climate (NSF, n.d.).

\section{Recommendations and Conclusion}

Two decades of NSF ADVANCE funded research on institutional interventions in academia has improved our understanding of the causes, consequences, and potential solutions for gender inequality in STEM. Not all academics and faculty administrators feel competent in implementing diversity interventions, thus researchers can provide many resources to create and 
implement these effective interventions at one's home institution. Researchers funded by an ADVANCE grant have created a Strategies for Effecting Gender Equity and Institutional Change (StratEGIC) Toolkit (https://www.colorado.edu/eer/sites/default/files/attachedfiles/userguide010816_1.pdf ) that provides resources shown to be effective in STEM environments (Laursen \& Austin, 2014). Their initial results have suggested three broad approaches to creating equality including (a) forming a leadership team that is diverse and supports equality initiatives, (b) creating strategic communication focused on equality goals, and (c) implementing change interventions to achieve equality for women and racial minorities in STEM. The StratEGIC Toolkit has only been tested and implemented in the academic context, but the potential for generalizations to other organizational contexts, such as STEM industries, is promising. The toolkit is a starting point for academics, administrators, and practitioners to jumpstart their efforts rather than using untested interventions.

Beyond the StratEGIC toolkit, academics and administrators should seek social scientists or intervention trained STEM faculty as possible collaborators for developing and implementing interventions within their organization. This type of collaboration could improve organizations through evidence-based practices and boost the organization's profile through a positive reputation (Cascio, 2008).

Women remain underrepresented in the STEM academic workforce, but we have identified effective interventions to help organizations address this inequity. Using an organizational change lens allows researchers to investigate the complex reasons why underrepresentation and inequality persist beyond the limited view of individual choices (Miner et al., 2018). A focus on systemic issues and academic cultural change can better integrate women into the STEM academic realm. 


\section{Conflict of Interest Statement}

The authors have no conflict of interest.

\section{Author Contributions}

All authors had full access to all the data in the study and take responsibility for the integrity of the data and the accuracy of the analysis. Conceptualization, B.J.C.; Methodology,

B.J.C.; Investigation, B.J.C., J.E.F., C.E.G., M.M.K., A.C.R., D.Y.H., and Z.W.P.; Formal Analysis, B.J.C., J.E.F., C.E.G., M.M.K.; Writing-Original Draft, B.J.C., J.E.F., C.E.G., M.M.K., A.C.R., D.Y.H., and Z.W.P.; Writing -Review \& Editing, B.J.C., J.E.F., C.E.G., M.M.K., and Z.W.P.; Visualization, B.J.C.; Supervision, B.J.C. 


\section{References}

Abramo, G., D’Angelo, C. A., \& Murgia, G. (2013). Gender differences in research collaboration. Journal of Informetrics, 7(4), 811-822.

ADVANCE Program. University of Michigan. (n.d.) ADVANCE Program: About Launch. Retrieved from https://advance.umich.edu/wp-content/uploads/2019/09/LauncheeHandout.pdf

Austin, A. E., \& Laursen, S. L. (2014). Strategic intervention brief \#3. Mentoring and networking activities. In S. L. Laursen, \& A. E. Austin (Eds.), StratEGIC Toolkit: Strategies for effecting gender equity and institutional change. Boulder, CO, and East Lansing, MI. www.strategictoolkit.org

Bagilhole, B. (2017). Being different is a very difficult row to hoe: Survival strategies of women academics. In J. Quinn, S. Davies, \& C. Lubelska (Eds.), Changing the Subject: Women in higher education (pp. 15-28). London, England: Taylor \& Francis.

Belle, D., Smith-Doerr, L., \& O’Brien, L. M. (2014). Gendered networks: Professional connections of science and engineering faculty. Advances in Gender Research, 19, $153-175$.

Bourdieu, P. (1986). The forms of capital. In N. W. Biggart (Ed.), Handbook of theory and research for the sociology of education (241-258). New York, NY: Greenwood.

Bozeman, B., \& Corley, E. (2004). Scientists' collaboration strategies: implications for scientific and technical human capital. Research Policy, 33(4), 599-616.

Burgess, D. J., Joseph, A., Van Ryn, M., \& Carnes, M. (2012). Does stereotype threat affect women in academic medicine? Academic Medicine, 87(4), 506-512.

Callister, R. R. (2006). The impact of gender and department climate on job satisfaction 
and intentions to quit for faculty in science and engineering fields. The Journal of Technology Transfer, 31(3), 367-375.

Carnes, M., Fine, E., \& Sheridan, J. (2019). Promises and pitfalls of diversity statements:

Proceed with caution. Academic Medicine, 94(1), 20-24.

Carrigan, C., Quinn, K., \& Riskin, E. A. (2011). The gendered division of labor among STEM faculty and the effects of critical mass. Journal of Diversity in Higher Education, 4(3), 131.

Casad, B. J., \& Bryant, W. J. (2016). Addressing stereotype threat is critical to diversity and inclusion in organizational psychology. Frontiers in Psychology, 7, 1-18.

Casad, B. J., Petzel, Z. W., \& Ingalls, E. A. (2019). A model of threatening academic environments predicts women STEM majors' self-esteem and engagement in STEM. Sex Roles: A Journal of Research, 80(7-8), 469-488.

Cascio, W. F. (2008). To prosper, organizational psychology should... bridge application and scholarship. Journal of Organizational Behavior: The International Journal of Industrial, Occupational and Organizational Psychology and Behavior, 29(4), 455-468.

Ceci, S., Williams, W., \& Barnett, S. (2009). Women's underrepresentation in science: Sociocultural and biological considerations. Psychological Bulletin, 135, 218-261.

Ceci, S. J., \& Williams, W. M. (2015). Women have substantial advantage in STEM faculty hiring, except when competing against more-accomplished men. Frontiers in Psychology, $6,1-10$.

Cheryan, S., Plaut, V. C., Davies, P. G., \& Steele, C. M. (2009). Ambient belonging: How stereotypical cues impact gender participation in computer science. Journal of Personality and Social Psychology, 97(6), 1045-1060. 
Cohen, G. L., \& Garcia, J. (2008). Identity, belonging, and achievement: A model, interventions, implications. Current Directions in Psychological Science, 17(6), 365-369.

Collins, R., \& Steffen, N. (2019). Hidden patterns: Using social network analysis to track career trajectories of women STEM faculty. Equality, Diversity and Inclusion, 38(2), 265-282.

Committee on Underrepresented Groups and the Expansion of the Science and Engineering Workforce Pipeline. (2011). Expanding underrepresented minority participation: America's science and technology talent at the crossroads. Washington, DC: National Academies Press.

Cundiff, J. L., Zawadzki, M. J., Danube, C. L., \& Shields, S. A. (2014). Using experiential learning to increase the recognition of everyday sexism as harmful: The WAGES intervention. Journal of Social Issues, 70(4), 703-721.

Curtis, J. W. (2014). The employment status of instructional staff members in higher education, Fall 2011. Washington, DC: American Association of University Professors.

Deci, E. L., Ryan, R.M. (1985). Intrinsic motivation and self-determination in human behavior. New York, NY: Plenum.

Deci, E. L., \& Ryan, R. M. (2000). The "what" and "why" of goal pursuits: Human needs and the self-determination of behavior. Psychological Inquiry, 11(4), 227-268.

Diekman, A. B., Weisgram, E. S., \& Belanger, A. L. (2015). New routes to recruiting and retaining women in STEM: Policy implications of a communal goal congruity perspective. Social Issues and Policy Review, 9(1), 52-88.

El-Alayli, A., Hansen-Brown, A. A., \& Ceynar, M. (2018). Dancing backwards in high heels: Female professors experience more work demands and special favor requests, particularly from academically entitled students. Sex Roles, 79(3-4), 136-150. 
Elsbach, K. D. (2003). Relating physical environment to self-categorizations: Identity threat and affirmation in a non-territorial office space. Administrative Science Quarterly, 48(4), 622-654.

Etzkowitz, H., Kemelgor, C., \& Uzzi, B. (2000). Athena unbound: The advancement of women in science and technology. Cambridge University Press.

Eveline, J. (2004). Ivory basement leadership: Power and invisibility in the changing university. Crawley, Western Australia: University of Western Australia Press.

Fassiotto, M., Hamel, E. O., Ku, M., Correll, S., Grewal, D., Lavori, P., . . Valantine, H. (2016). Women in academic medicine: Measuring stereotype threat among junior faculty. Journal of Women's Health, 25(3), 292-298.

Fernandez, E. C., Popović, D., \& Gilmer, P. J. (2014). Recruiting women STEM faculty. In Alliances for Advancing Academic Women (pp. 121-145). Rotterdam, Netherlands: SensePublishers.

Ginther, D. K., \& Kahn, S. (2013). Education and academic career outcomes for women of color in science and engineering. In K. Matchett (Ed.), Seeking solutions: Maximizing American talent by advancing women of color in academia (pp. 71-92). Washington, DC: National Academies Press.

Griffith, A. L. (2010). Persistence of women and minorities in STEM field majors: Is it the school that matters? Economics of Education Review. 29(6), 911-22.

Gunter, R., \& Stambach, A. (2005). Differences in men and women scientists' perceptions of workplace climate. Journal of Women and Minorities in Science and Engineering, 11(1), 97-116. 
Florida International University ADVANCE. (2019). Diversity Mentor Professorships. Retrieved from https://advance.fiu.edu/programs/diversity-mentor-professorships/index.html

Hall, W. M., Schmader, T., \& Croft, E. (2015). Engineering exchanges: Daily social identity threat predicts burnout among female engineers. Social Psychological and Personality Science, 6(5), 528-534.

Handelsman, J., Pfund, C., Lauffer, S. M., \& Pribbenow, C. M. (2005). Entering mentoring: A seminar to train a new generation of scientists. Madison, WI: Board of Regents of the University of Wisconsin System.

Hennes, E. P., Pietri, E. S., Moss-Racusin, C. A., Mason, K. A., Dovidio, J. F., Brescoll, V. L., ... Handelsman, J. (2018). Increasing the perceived malleability of gender bias using a modified Video Intervention for Diversity in STEM (VIDS). Group Processes \& Intergroup Relations, 21(5), 788-809.

Huang, J., Gates, A. J., Sinatra, R., \& Barabási, A. L. (2020). Historical comparison of gender inequality in scientific careers across countries and disciplines. Proceedings of the National Academy of Sciences. Online First February 18, 2020.

doi:10.1073/pnas.1914221117

Jackson, J. K., Meija, A., Stoiko, R., \& Holmes, M. H. (2016). Dialogues toward gender equity: Engaging engineering faculty to promote inclusive department climate. American Society for Engineering Education. Conference Proceedings. Retrieved from https://peer.asee.org/26835

James, S. M., \& Singer, S. R. (2016). From the NSF: The National Science Foundation's investments in broadening participation in science, technology, engineering, and 
mathematics education through research and capacity building. CBE_Life Sciences Education, 15(3), fe7.

Kachchaf, R., Ko, L., Hodari, A., \& Ong, M. (2015). Career-life balance for women of color: Experiences in science and engineering academia. Journal of Diversity in Higher Education, 8(3), 175-191.

Kaminski, D., \& Geisler, C. (2012). Survival analysis of faculty retention in science and engineering by gender. Science, 335(6070), 864-866.

Korte, R., \& Lin, S. (2013). Getting on board: Organizational socialization and the contribution of social capital. Human Relations, 66(3), 407-428.

Laursen, S. L., \& Austin, A. E. (2014). StratEGIC Toolkit: Strategies for effecting gender equity and institutional change. Boulder, CO, and East Lansing, MI. www.strategictoolkit.org

Lester, J. (2008). Performing gender in the workplace: Gender socialization, power, and identity among women faculty members. Community College Review, 35(4), 277-305.

Magua, W., Zhu, X., Bhattacharya, A., Filut, A., Potvien, A., Leatherberry, R., . . Kaatz, A. (2017). Are female applicants disadvantaged in National Institutes of Health peer review? Combining algorithmic text mining and qualitative methods to detect evaluative differences in R01 reviewers' critiques. Journal of Women's Health, 26(5), 560-570.

Malone, K. R., \& Barabino, G. (2009). Narrations of race in STEM research settings: Identity formation and its discontents. Science Education, 93(3), 485-510.

Marin-Spiotta, E., Barnes, R., Berhe, A. A., Hastings, M. G., Mattheis, A., Schneider, B., \& Williams, B. M. (2017, December). From the classroom to the field: Intervention training to address sexual harassment in the geosciences. In American Geophysical Union Fall Meeting Abstracts. 
Marin-Spiotta, E., Barnes, R. T., Berhe, A. A. A., Hastings, M. G., Mattheis, A., Schneider, B., ... \& Bell, C. F. (2019, December). ADVANCEGeo Partnership: Empowering geoscientists to transform workplace climate through bystander intervention and research ethics training. In American Geophysical Union Fall Meeting.

McDermott, M., Gelb, D. J., Wilson, K., Pawloski, M., Burke, J. F., Shelgikar, A. V., \& London, Z. N. (2018). Sex differences in academic rank and publication rate at top-ranked US neurology programs. JAMA Neurology, 75(8), 956-961.

Mitchneck, B. (2008). National Science Foundation [0820212]. Revealing the cumulative effects of subtle gender bias via brief workshop activity.

Miner, K. N., January, S. C., Dray, K. K., \& Carter-Sowell, A. R. (2019). Is it always this cold? Chilly interpersonal climates as a barrier to the well-being of early-career women faculty in STEM. Equality, Diversity and Inclusion: An International Journal, 38(2), 226-245.

Moss-Racusin, C. A., Molenda, A. K., \& Cramer, C. R. (2015). Can evidence impact attitudes? Public reactions to evidence of gender bias in STEM fields. Psychology of Women Quarterly, 39(2), 194-209.

Moss-Racusin, C. A., Pietri, E. S., Hennes, E. P., Dovidio, J. F., Brescoll, V. L., Roussos, G., \& Handelsman, J. (2018). Reducing STEM gender bias with VIDS (video interventions for diversity in STEM). Journal of Experimental Psychology: Applied, 24(2), 236-260.

Moss-Racusin, C. A., van der Toorn, J., Dovidio, J. F., Brescoll, V. L., Graham, M. J., \& Handelsman, J. (2014). Scientific diversity interventions. Science, 343(6171), 615-616. National Institutes of Health (NIH). (2019). Research to Understand and Inform Interventions that Promote the Research Careers of Individuals in the Biomedical Sciences. Retrieved from: https://grants.nih.gov/grants/guide/pa-files/PAR-19-295.html 
National Science Foundation [NSF]. (2019a, March). Women, Minorities, and Persons with Disabilities in Science and Engineering. Retrieved from https://ncses.nsf.gov/pubs/nsf19304/

National Science Foundation [NSF]. (2019b). ADVANCE: Organization change for gender equity in STEM academic professions. Retrieved from https://www.nsf.gov/pubs/2019/nsf19552/nsf19552.htm

National Science Foundation [NSF]. (n.d.) ADVANCE at a glance. Retrieved from https://www.nsf.gov/crssprgm/advance/

Nemiro, J. E., Hacker, B., Ferrel, M. L., \& Guthrie, R. (2009). Using appreciative inquiry as a tool to instigate transformational change in recruiting and developing women faculty in STEM disciplines. International Journal of Gender, Science and Technology, 1(1).

Ng, E. S., \& Burke, R. J. (2005). Person-organization fit and the war for talent: Does diversity management make a difference? The International Journal of Human Resource Management, 16(7), 1195-1210.

Pfund, C., House, S., Spencer, K., Asquith, P., Carney, P., Masters, K. S., McGee, R., Shanedling, J., Vecchiarelli, S., \& Fleming, M. (2013). A research mentor training curriculum for clinical and translational researchers. Clinical and Translational Science, 6(1), 26-33.

Pietri, E. S., Hennes, E. P., Dovidio, J. F., Brescoll, V. L., Bailey, A. H., Moss-Racusin, C. A., \& Handelsman, J. (2019). Addressing unintended consequences of gender diversity interventions on women's sense of belonging in STEM. Sex Roles, 80(9-10), 527-547. 
Pietri, E. S., Moss-Racusin, C. A., Dovidio, J. F., Guha, D., Roussos, G., Brescoll, V. L., \& Handelsman, J. (2017). Using video to increase gender bias literacy toward women in science. Psychology of Women Quarterly, 41(2), 175-196.

Purdie-Vaughns, V., Steele, C. M., Davies, P. G., Ditlmann, R., \& Crosby, J. R. (2008). Social identity contingencies: How diversity cues signal threat or safety for African Americans in mainstream institutions. Journal of Personality and Social Psychology, 94(4), 615.

Rhoten, D., \& Pfirman, S. (2007). Women in interdisciplinary science: Exploring preferences and consequences. Research Policy, 36(1), 56-75.

Riffle, R., Schneider, T., Hillard, A., Polander, E., Jackson, S., DesAutels, P., \& Wheatly, M. (2013). A mixed methods study of gender, STEM department climate, and workplace outcomes. Journal of Women and Minorities in Science and Engineering, 19(3), 227-243.

Rosser, S. V. (2004). Using POWRE to ADVANCE: Institutional barriers identified by women scientists and engineers. National Women's Studies Association Journal, 16, 50-78.

Rosser, V. J. (2004). Faculty members' intentions to leave: A national study on their work life and satisfaction. Research in Higher Education, 45(3), 285-309.

Rosser, S. V., \& Lane, E. O. N. (2002). Key barriers for academic institutions seeking to retain female scientists and engineers: Family-unfriendly policies. Low Numbers, stereotypes, and harassment. Journal of Women and Minorities in Science and Engineering, 8(2), 161-189.

Salmon, A. (2015). A complex formula: Girls and women in science, technology, engineering and mathematics in Asia. Bangkok, Thailand: UNESCO Bangkok. 
Savory, J. N. (2013, June). Women in technology sharing online (WitsOn): Assessing usage, satisfaction, and outcomes from an e-mentoring course. Women in Engineering Programs \& Advocates Network (WEPAN). Conference proceedings.

Schmader, T., Johns, M., \& Forbes, C. (2008). An integrated process model of stereotype threat effects on performance. Psychological Review, 115, 336-356.

Seifert, T., \& Umbach, P. (2008). The effects of faculty demographic characteristics and disciplinary context on dimensions of job satisfaction. Research in Higher Education, $49,357-381$.

Settles, I. H., Cortina, L. M., Malley, J., \& Stewart, A. J. (2006). The climate for women in academic science: The good, the bad, and the changeable. Psychology of Women Quarterly, 30(1), 47-58.

Shea, C. M., Malone, M. F. F. T., Young, J. R., \& Graham, K. J. (2019). Interactive theater: an effective tool to reduce gender bias in faculty searches. Equality, Diversity and Inclusion: An International Journal, 38(2), 178-187.

Sheridan, J., Benting, D., \& Pribbenow, C. M. (2004, July). Evaluation of women faculty mentoring program at the University of Wisconsin Madison. Madison, WI: University of Wisconsin, Madison.

Smith, C. A. (2014). Assessing academic STEM women's sense of isolation in the workplace. In Alliances for Advancing Academic Women (pp. 97-117). SensePublishers, Rotterdam.

Smith, J. L., Handley, I. M., Zale, A. V., Rushing, S., \& Potvin, M. A. (2015). Now hiring! Empirically testing a three-step intervention to increase faculty gender diversity in STEM. BioScience, 65(11), 1084-1087. 
Steele, C. M., \& Aronson, J. (1995). Stereotype threat and the intellectual test performance of African Americans. Journal of Personality and Social Psychology, 69(5), 797.

Stephens, N. M., Fryberg, S. A., \& Markus, H. R. (2012). It's your choice: How the middle-class model of independence disadvantages working-class Americans. In S. T. Fiske \& H. R. Markus (Eds.), Facing social class: How societal rank influences interaction (pp. 87 106). New York, NY: Russell Sage Foundation.

Towns, M. H. (2010). Where are the women of color? Data on African American, Hispanic, and Native American faculty in STEM. Journal of College Science Teaching, 39(4), 8-9.

University of California Office of the General Counsel. (2015). Guidelines for Addressing Race and Gender Equity in Academic Programs in Compliance with Proposition 209. [Brochure]. CA, USA: Author. Retrieved from https://aadocs.ucdavis.edu/training/stead-faculty-search-committee workshops/guidelines-for-addressing-race-and-gender-equity-in-academic-programs-in compliance-with-prop-209.pdf

UTRGV. (n.d.). Education \& Empowerment. Retrieved from https://www.utrgv.edu/advance/components-initiatives/education-empowerment/ Valian, V. (2005). Beyond gender schemas: Improving the advancement of women in academia. Hypatia, 20(3), 198-213.

Walker, H. J., Feild, H. S., Bernerth, J. B., \& Becton, J. B. (2012). Diversity cues on recruitment websites: Investigating the effects on job seekers' information processing. Journal of Applied Psychology, 97(1), 214.

Walters, J., \& McNeely, C. L. (2010). Recasting Title IX: Addressing gender equity in the 
science, technology, engineering, and mathematics professoriate. Review of Policy Research, 27(3), 317-332.

Willemsen, T. M., \& Van Vianen, A. M. (2014). Gender issues in work and organizations. In L. Steg, A. P. Buunk, \& J. A. Rothengatter (Eds.), Applied social psychology: Understanding and managing social problems (pp. 206-225). Cambridge, UK: Cambridge University Press.

WISELI. (2015). Enhancing department climate: A guide for department chairs. [Brochure]. WI, USA. Retrieved from https://wiseli.wisc.edu/wp content/uploads/sites/662/2018/10/ClimateBrochure.pdf

Women into Science and Engineering [WISE]. (2019, December). 2019 Workforce Statistics. Retrieved from https://www.wisecampaign.org.uk/statistics-category/workforce/

Xu, Y. J. (2008). Gender disparity in STEM disciplines: A study of faculty attrition and turnover intentions. Research in Higher Education, 49(7), 607-624.

Young, C. J., MacKenzie, D. L., \& Sherif, C. W. (1980). In search of token women in academia. Psychology of Women Quarterly, 4(4), 508-525. 